\title{
LEGAL LITERATURE IN HONG KONG
}

PETER WESLEY-SMTrH, B.A., LL,B, Mh.D.

tectarer in thaw

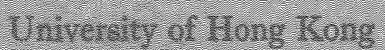

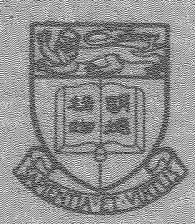

Centre of Astan Studics UNIVERSITY OF HONG RONG 


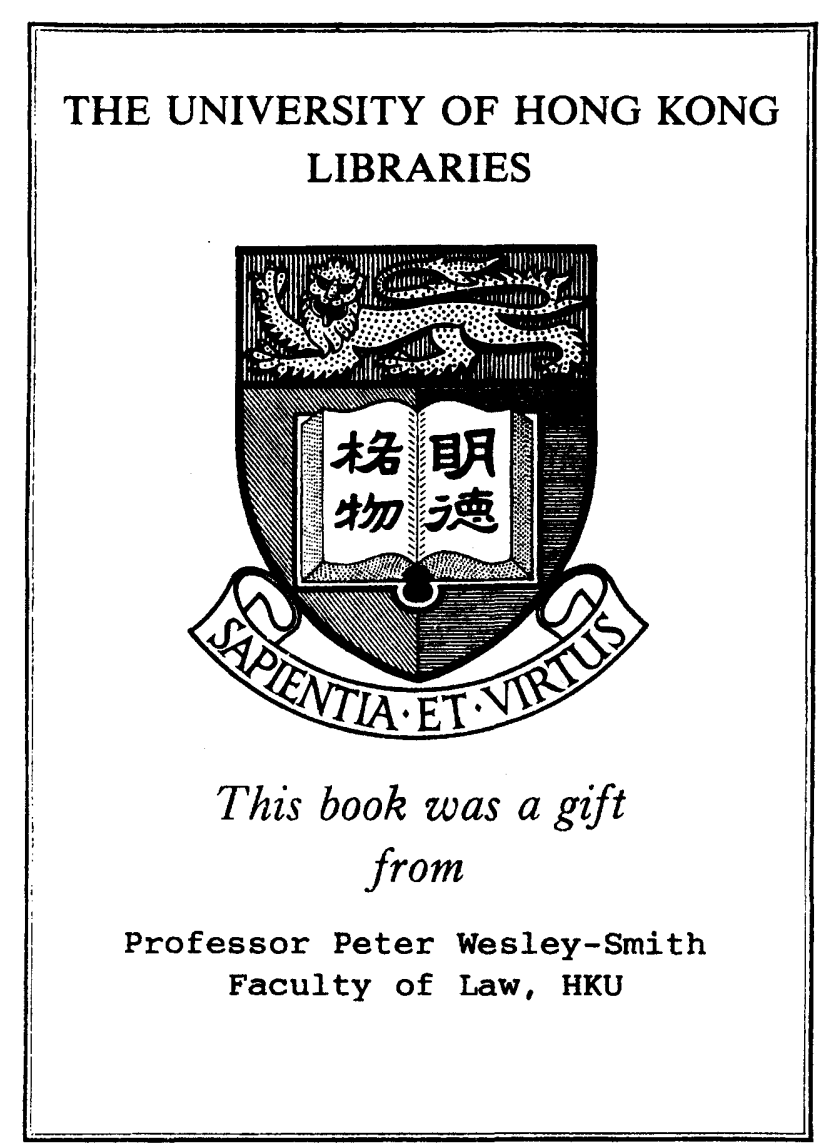




\section{LEGAL LITERATURE I $\mathrm{HONG}$ KONG}

PETER WESLEY-SMITH School of Law Res: $7 D / 6 M$ Bowen Road Hong Kong 250883

PETER WESLEY-SMITH, B.A., LL,B., Ph.D. Lecturer in Law

University of Hong Kong
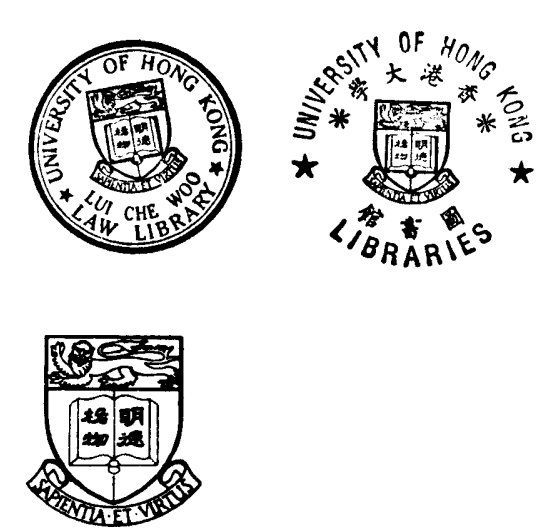

Centre of Asian Studies UNIVERSITY OF HONG KONG I 979 
(C) Copyright by the University of Hong Kong, 1979

ISSN HKO44I-I900
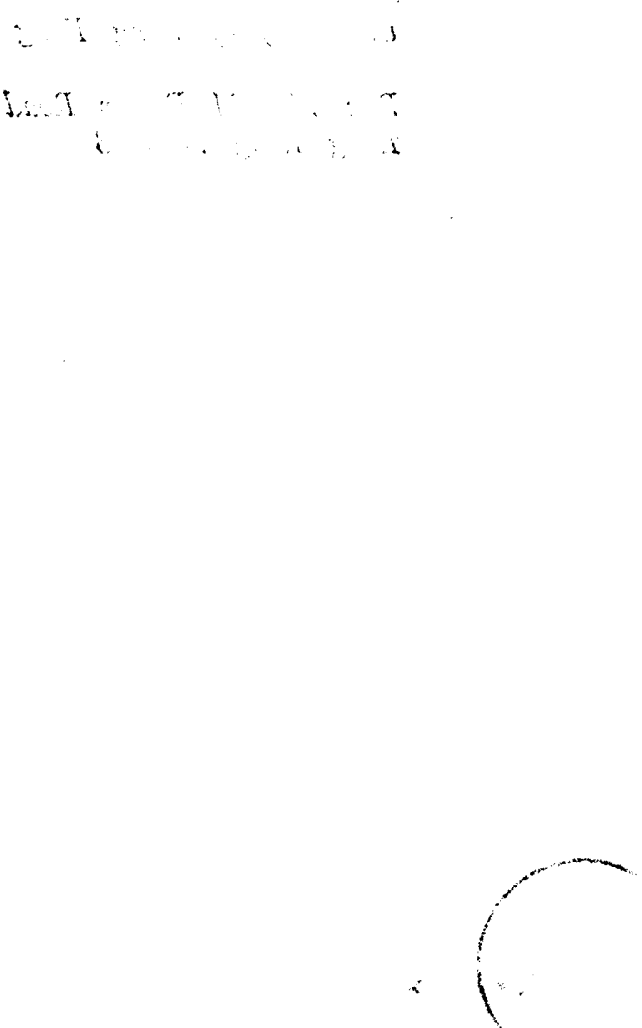

Centre of Asian Studies Bibliographies and Research Guides, No. I7 $H K \$ 10.00$

General Editor: FRANK H. H. KING

The Centre of Asian Studies is established to provide a focal point for the activities of the University of Hong Kong in the areas of East and Southeast Asia, research assistance to scholars in these fields and with special reference to Hong Kong, and physical and administrative facilities for research, seminars, and conferences dealing with both traditional and modern aspects of Asian Studies.
THIS STUDY was originally prepared for a seminar on legal literature in small jurisdictions held in Toronto in November 1978. It follows the format which was suggested in the instructions to paper writers. The opportunity has been taken to bring the information up to date and to rewrite some paragraphs

though the paper is otherwise little changed.

"Legal literature" is probably incapable of precise definition. I take it to include published material by which one can discover what the law is (primary literature) and in which the law is described, discussed, analysed, criticised and so on (secondary literature).

I assume that the development of a local legal literature is a thing of value. It is much easier to assume this than to demonstrate it. But if such general notions as a government of laws and the rule of law are accepted, it necessarily follows that the citizen must be readily able to discover and understand what the rules governing his conduct are. And if emphasis is placed on the "art" of achieving "legality" and the creation and maintenance of a healthy legal system, ${ }^{1}$ the importance of legal literature is even more obvious. At the level of the technical operation of the system, where such basic precepts as stare decisis and the supremacy of the legislature over common law are taken for granted, easy access to law reports and the statute book, and to commentaries upon these, is fundamental.

See, for example, Lon L Fuller, The Morality of Law (New Haven and London Yale University Press, rev ed 1969), and Joseph Raz, "The Rule of Law and its Virtue" (1977) 93 LQR 195. 
In formal terms, therefore, it is a simple matter to indicate why it is justified to assume the value of legal literature. Of course, it may be that in individual cases justice is not well served by a highly developed legal literature: "palm-tree justice" might be preferred, or the demands of an on-going social revolution might severely lessen the need for published materials on the law. Legal literature in a place like Hong Kong might even be deplored as contributing to the efficiency of a colonial legal system which should be weakened and destroyed, not strengthened. But these matters are not the concern of this paper.

If legal literature is important, it should reflect the social context of the law: it should be localised. The social and cultural environment of Hong Kong is in some respects far different from that in which the common law developed, and imported legal principles and rules may require constant, careful assessment and adjustment if they are to be appropriate. A transplanted common law will flourish, said Denning IJ in Nyali Ltd v Attorney General, ${ }^{2}$ but it needs careful tending.

"It has many principles of manifest justice and good sense which can be applied with advantage to peoples of every race and colour all the world over: but it has also many refinements, subtleties and technicalities which are not suited to other folk. These offshoots must be cut away. In these far-off lands the people must have a law which they understand and which they will respect.

The common law cannot fulfil this role except with considerable qualifications. The task of making these qualifications is entrusted to the judges of these lands. It is a great task which calls for all their wisdom."

That wisdom can be crucially assisted by a literature devoted to critical analysis of English law in a local context. ${ }^{3}$

2 [1956] 1 QB 1, 16-17.

3 See also the comments by Henry Litton $Q C$ in the Hong Kong Bar Association Annual Statement 1978/79, pp 7-8.
One question which was raised at the Toronto seminar related to the effect in functional terms of an abundance or an absence of legal literature in a particular legal system. I make no attempt to answer that question here. Neither do I discuss the suggested topic "information needs and present user habits."

This paper owes much to Professor William Twining, who initiated the legal literature in small jurisdictions project, and to his assistant Ms Jenny Uglow.

Peter Wesley-Smith

School of Law

University of Hong Kong

April, 1979 


\section{CONTENTS}

I PARTICULAR FEATURES AND PROBLEMS OF

THE JURISDICTION

The setting

$$
\begin{array}{ll}
\text { I.1. } & \text { The city-state of Hong Kong } \\
\text { I.2. } & \text { Acquisition of Hong Kong } \\
\text { I.3. } & \text { Constitutional structure } \\
\text { I.4. } & \text { Legal sources of Hong Kong law } \\
\text { I.5. } & \text { General remarks }
\end{array}
$$

British law in a Chinese context

$$
\begin{array}{ll}
\text { I.6. The legal system } \\
\text { I.7. Different language groups }
\end{array}
$$

General problems

I.8. Rapid legislative change

I.9. Conflicting interests between professional

I.10. Small markets for local educational

$$
\text { material }
$$

II HISTORICAL EVOLUTION OF LEGAL LITERATURE IN HONG KONG

Statute law

II.1. Revised editions of the laws

Law reports
II.2. The Hong Kong Law Reports

Secondary material

II.3. The early development of university education

II.4. The Keeton initiative

II.5. A law journal

II.6. Non-Hong Kong emphasis

II.7. The development of university law teaching

II.8. Amount of legal literature

Imported versus locally produced materials

II.9. The use of English materials

IT.10. The scope for local legal literature

III EXISTING MATERIALS

Statutes

III.1. The statute book described

III.2. In praise of the statute book

III.3. Criticisms of the statute book

III.4. The government Gazette
Law reports

III.5. The flong Kong Law Reports described

III.6. Assessment of the Hong Kong Law Reports

III.7. Reform of the Hong Kong Law Reports

III.8. Unreported judgments

III.9. Hong Kong Law Journal road traffic summaries

$$
\text { and sentencing section }
$$

III.10. Circulated headnotes

III.11. Tribunal decisions

Legal archive

III.12. The Public Record office

Secondary materials

III.13. The paucity

II.14. The Hong Kong Law Journal

III.15. Financial viability

III.16. Hong Kong Law Journal Limited

III.17. Other periodicals

III.18. The cost factor

IV RESOURCES AND CONDITIONS

Personnel resources

IV.1. Potential authors

IV.2. The record of the teaching profession

IV.3. Teachers in private practice

IV.4. Opportunities

Financial resources
IV. 5 .
Grants for research and publishing

Facilities for research

IV.6. Law libraries

FUTURE DEVELOPMENTS

V.l. The size of the market

V.2. Legal research unit

V.3. Computerisation of legal material

V.4. Hong Kong Law Journal Limited

v.5. Other publishers

V.6. Needs

V.7. The meting of needs

V.8. Conclusion

Appendix 1: Extract from the interim report of the Attorney General's working party on law reporting

Appendix 2: A bibliography of writings on Hong Kong law 
PARTICULAR FEATURES AND PROBLEMS

OF THE JURISDICTION

The setting

I.1. The city-state of Hong Kong.

The "city-state" of Hong Kong is actually twin cities with rapidly growing satellite towns in their rural hinterland. The total area is just over 400 square miles (1,049 square kilometres), consisting of mainland and numerous islands. Much of it is mountainous, and the vast proportion of Hong Kong people live in urban areas and depend on imports, mostly from China, for food. The population is estimated to be 4 million people $(4,720,200$ at the end of 1978). More than 98 per cent of these are Chinese, predominantly Cantonese, and they are culturally cohesive and conservative, in some ways remarkably little affected by Western influences. ${ }^{4}$ The economy of Hong Kong is primarily industrial, though commerce plays an important part. Historically, Hong Kong owes its economic survival to its port and its position on the south China coast: its traditional economy was entrepòt trading and financing between China and other countries. But establishment of the People's Republic in 1949 and the United States embargo on trade with China after Chinese entry into the Korean war forced Hong Kong to switch rapidly to industry, based mainly on light manufacturing. The economy is adamantly capitalist and the government, in many areas, is content to let market forces prevail.

I.2. Acquisition of Hong Kong.

Hong Kong is a British colony carved out of China in three stages: by cession, in 1842 and 1860, and by lease, in 1898. The lease agreement covers by far the greater land area of Hong Kong and is due to expire in 1997. The People's Republic of China does not recognise the validity of any of the nineteenth

4 Details taken from Hong Kong 1979 (Hong Kong: Government Press, 1979) (the government's glossy annual report). 
century Sino-British treaties and has declared Hong Kong to be part of Chinese territory occupied by the British authorities; the "question" of Hong Kong is to be "settled in an appropriate way when conditions are ripe." 5

I.3. Constitutional structure. ${ }^{6}$

Constitutionally, Hong Kong is a colony of Great Britain. The principal

administrator is a governor appointed by and responsible to the British government through the Foreign and Commonwealth office. He is advised by an Executive Council, which is composed of unoffictal, official and ex officio members. Of a similar composition is the Legislative Council, the principal legislative assembly in and for the colony. The governor is not obliged to sign into law bills which are presented for his assent, though he always does so. He is required to reserve some bills for the royal assent, and local ordinances may be disallowed or declared to be repugnant to an applicable Act of Parliament. In practice, however, there is little restriction on the local government's legislative power.

I.4. Legal sources of Hong Kong law.

These are:

(1) Acts of the United Kingdom Parliament which apply by their own terms (express or implied) or are applied by prerogative order in Council, imperial subsidiary legislation or ordinance of the Hong Kong legislature;

(2) Orders in Council (under prerogative or statutory authority) and other prerogative legislative instruments made specially for Hong Kong or generally for dependent British territories;

5 The phrase used in the letter of March 8, 1972, from the Permanent Representative of China to the United Nations to the Chairman of the Special Committee of 24.

6 The definitive account is by John Rear, "The Law of the Constitution" in Hopkins (ed), Hong Kong: The Industrial Colony (Hong Kong: Oxford UP, 1971). For a short introductory essay see the booklet on Hong Kong in Blaustein and Blaustein (eds), Constituti
(New York: Oceana, 1976).

7 See the Application of English Law Ordinance (cap 88, LHK 1972 ed).
(3) local ordinances and subsidiary legislation not disallowed and not repugnant to superior legislation;

(4) English common law, equity and practice and procedure not inapplicable to the circumstances of the colony (dectsions of the House of Lords and of the Privy Council are considered binding by Hong Kong courts, and English Court of Appeal decisions are highly persuasive);

(5) "Hong Kong common law" (a small category consisting of local judicial decisions applying rules not part of English common law, for example rules from the residue of Chinese law and custom which still applies). The bulk of the statute law emanates from the local legislature, though much of it is modelled on British legislation while the English common law applies virtually in toto. The law is administered by a court system at the apex of which is the Judicial Committee of the Privy Council (which hears about five appeals from Hong Kong per year). Within the colony, minor crime is dealt with by magistrates; middle-range crime goes before the District Court; indictable offences are usually heard before a judge and jury in the High court. Small civil claims are the preserve of a special tribunal, and other civil matters are taken to the District Court or the High Court. The Court of Appeal is the highest court in Hong Kong, while at the lower end of the scale are the Labour Tribunal and the Tenancy Tribunal. The Lands Tribunal occupies an intermediate position.

\section{I.5. General remarks.}

The facts and factors mentioned above lead to the following generalisations which are relevant to any discussion of legal literature in Hong Kong - though they are rather speculative and research is needed to verify them:

(1) Although the economic history of Hong Kong is one long success story, there is a continual sense of impermanence and vulnerability: Hong Kong is largely dependent on trade with other countries for its raw materials, many finished products, and even for food and water.

Politically the situation is the same: a British colony in an age of anti-imperialism, a territory regarded by the Communist regime in China as Chinese and of which the greater part reverts to China anyway in 
less than twenty years' time. For the Western businessman, Hong Kong has always been a place in which to make large profits in a relatively short period before going home to enfoy them: the British have not "settled" their colony. For many of the Chinese, Hong Kong has been a place of refuge providing a temporary respite from less attractive social condtions in China; but the ultimate aim, or the ultimate destiny, is to return to the native soil. The argument here, therefore, is that there is less a sense of community, of permanence, or of national or local consciousness in Hong Kong than in many other jurisdictions in the common law world. Thus there is no real sense of a local culture. More specifically for our purposes, there is no cultural context in which a local legal literature could develop.

(2) In addition, there is no fully developed "legal culture" in Hong Kong. Confucian concepts of social organisation emphasised conciliation and mediation at the expense of confrontation and sought a solution to disputes which was least disruptive to society. This idea contrasts strongly with the Western ldea of litigation and a government of laws. Thus resort to lawyers and the courts, in Hong Kong as in traditional China, has generally been undertaken reluctantly. Partly for this reason (a relative lack of demand), the legal profession in Hong Kong has always been small.

(3) Given Hong Kong's economic situation, there is a market for legal practitioners who specialise in such areas as international trade, company law, taxation and shipping law. The financial rewards for the able practitioner in these areas of law are considerable, and this, combined with the small number of lawyers, has ensured an understandable concentration of expertise into a fairly narrow range of legal services. Accordingly, there may be a demand for legal literature which analyses the applicable rules in profitable areas of law, but market forces are intimidating to the aspiring publisher of works on, for example, Hong Kong's legal system, public law, or legal history.
(4) In many areas of law the differences between English and Hong Kong law are non-existent or negligible: the statutes are virtually identical and the common law rules are the same. Thus, as far as doctrinal literature is concerned, reliance can be placed on English textbooks, articles in the learned journals, Halsbury's and so on. That is, there is no great demand for locally produced studies of this nature, which in any event are unlikely to improve on their English models. This is not to deny, however, that there are many areas of Hong Kong law for which English works are unsuitable and which deserve systematic exposition. of course, "law and society" or "law in context" studies from outside Hong Kong do not have much relevance to the colony, and there is an open field for this kind of legal scholarship.

British law in a Chinese context

\section{I.6. The legal system.}

The Hong Kong legal system is, of course, inherited from England: there is a similar general structure of courts, the same general rules apply to judges and practitioners, the laws themselves are often virtually identical. The differences between the Hong Kong and English legal systems are quite minimal: there has been very little "adaption of an inherited legal system to a new social or political situation" and thus no novel new system demanding study and provoking research. In addition, there has not been any clearly perceived need for a radical rethinking of the system as it works in Hong Kong. Thus the impetus for a local legal literature which analyses the system and studies its components has not existed. When the British commissions on the provision of legal services are concluded there may be pressure to investigate that topic in the specific context of Hong Kong; until then, the legal system will probably remain largely unexplored. ${ }^{8}$

8 See, however, my editorial comment in (1977) 7 HKLJ 289. 


\section{I.7. Different language groups.}

Chinese and English are both official languages in Hong Kong, though English predominates at the higher levels of government and is used by the personnel of most courts of law. Most children learn English at school, but probably only a small proportion of Hong Kong's young people reach a high degree of fluency in the written and spoken English word. This means that the market for legal literature in English is reduced from what it could potentially be, while publication in English and Chinese adds significantly to the cost. Since the education of aspiring lawyers is in English, and since many of the system's personnel do not read Chinese, it is unlikely that serious works of law would be published in Chinese only. If a market could be found for legal literature in Chinese, however, the diversification of dialects would of course present no problem, since each dialect has the same written script.

\section{General problems}

I.8. Rapid legislative change.

As described below (see paras IV.I and 2), the statute book in Hong Kong is a good one, and rapid changes in legislation can generally be easily followed by its users. Insofar as legislative change might rapidly outdate textbooks and other legal works, there is no such problem in Hong Kong owing to the general paucity of legal literature. In any event, however, in few areas of Hong Kong law is there any rapid legislative change. The government is normally reluctant to intervene in most areas of society, and the average legislative output is small. In the 1970s the annual number of ordinances has averaged about 85, many of them incorporating only minor amendments.

\section{I.9. Conflicting interests between professional and academic lawyers.}

There is so little legal publication of any sort in Hong Kong that anything of quality, unless particularly narrow in scope, is likely to appeal to all sectors of the legal world. In terms of sales, however, an author would be wise to write for the professional rather than the academic market. The Law Lectures for Practitioners series sells reasonably well (about 170 copies of each book) whereas one would imagine a similarly sized and priced book of general legal essays, for example, would scarcely sell at all. It is likely that many practitioners subscribe to the Hong Kong Law Journal for its personal injuries reports and sentencing section rather than for its academic articles.

I.10. Small markets for local educational material.

The market in Hong Kong for any kind of legal literature is tiny. The education market occupies a large proportion of it, yet many students are studying for exams in English law set by various English examining bodies and are not interested in Hong Kong varlants of the rules they are required to know. With some specific exceptions, students likely to be interested in locally produced legal literature are those in the law department of the University of Hong Kong and these students are much more likely to use library copies than to acquire their own. 


\section{CHAPTER II}

\section{HISTORICAL EVOLUTION OF LEGAL LITERATURE}

\section{IN HONG KONG}

\section{Statute law}

II.1. Revised editions of the laws.

In 1864 an ordinance "for compiling a New Edition of the ordinances of this Colony" was passed, empowering the governor to appoint two commissioners charged with the task of preparing, printing and publishing a revision of the ordinances. ${ }^{9}$ Eleven years later a similar measure, the Legislative Commissioners Ordinance, ${ }^{10}$ provided similar powers. Both ordinances were repealed in 1886 by the Statute Law Preservation Ordinance, ${ }^{11}$ whose preamble referred to a collection of ordinances from the commencement of the colony down to and inclusive of Ordinance No 30 of 1886. This collection was deposited with the registrar of the supreme court and was declared to be a true and authentic record of the ordinances comprised within it. The first specially printed and published edition of the ordinances of Hong Kong was that prepared by Mr A J Leach and produced in four volumes in 1887. Since then there have been periodic revisions: In 1904 by the Chief Justice, Sir John Carrington (up to the end of 1901), in 1913 by C G Alabaster (up to the end of 1912), in 1924 by Arthur Dyer Ball (up to the end of 1923), in 1938 by J A Fraser (up to the end of 1931), in 1950 by Sir John Bowes Griffin and others (up to Ordinance No 31 of 1950), and in 1966 by H A de Barros Botelho (up to December 31, 1964). (See para III.1 below.)

9 No 7 of 1864

10 No 10 of 1875 .

11 No 31 of 1886 . Ordinance No 10 of 1875 had the distinction of being repealed again, in No 29 of 1901.

\section{Law reports}

II.2. The Hong Kong Law Reports.

For the first sixty years or so of the Supreme Court's existence there was no organised official system of law reporting, nor were regular professional reports published by any private concern. The daily newspapers, it seems, provided the only source for reports of previous cases until 1905, when the Hong Kong Law Reports series was established. This series was probably instigated by the new Chief Justice, Sir Francis Piggott, who referred on his retirement to the "scrapbook days" which had preceded the reports. ${ }^{12}$ No other reports have emerged. J W Norton-Kyshe, who reported cases while in the Straits Settlements prior to his arrival in Hong Kong in 1896 as registrar of the Supreme Court, spent his time in Hong Kong writing a history and feuding with colleagues rather than carrying on the good work as a law reporter. ${ }^{13}$ The interim report of a working party on law reporting established by the Attorney General in 1978 noted:

"In the early years the work of editing and preparing of the Reports for publication was undertaken by members of the Judiciary. After World War II, barristers in private practice assisted by Mr. G S Edwards, Court Clerk to a puisne judge and later Deputy Registrar of the District Court, took over the editorial work. For their efforts the editors were paid an honorarium, the amount of which was calculated on the basis of $\$ 125$ for a Supreme Court case and $\$ 100$ for a District Court case. The sum so paid was taken into account in fixing the price of each issue of the Reports. In the early sixties, with legislation and litigation on the increase law reporting became too heavy a burden on private practitioners undertaking the work and delay in publication resulted. The Attorney General offered assistance and in late 1966 the editorship of the Hong Kong Law Reports was transferred to a Crown Counsel. Since 1969 the holder of the post of Law Reform Draftsman in the Legal Department also took on the added responsibilities of Editor of the Hong Kong Law Reports." See the unpaginated note bound in with volume 7 of the Hong Kong Law Reports (1912).

13 see my description of his Hong Kong career in (1972) 2 HKLJ 278. 
Since 1950 the reports have been printed and published by the Government Printer and sold and distributed by the Department of Information Services. Five hundred copies of each quarterly part are printed, of which 126 are distributed free to the judiciary and to some government departments and institutions and about 150 copies are sold to members of the public.

\section{Secondary material}

\section{II.3. The early development of university education.}

There was no university education in Hong Kong until 1911, when the University of Hong Kong was established. The founders envisaged a high-minded role for their institution as a bridge between East and West which would assist in the modernisation of China. A faculty of law was originally to be among the first three faculties in the university, and one of its main functions would have been, in Governor Lugard's words, the training of "sons of gentry who aim at official posts"14 - international law and treaties were mentioned as subjects of practical utility for this purpose. But when the university first opened its doors there was no provision for legal studies.

\section{II.4. The Keeton initiative.}

In Easter 1924, however, George $w$ Keeton arrived as Senior Lecturer in Political Science and Jurisprudence, and he began teaching these two subjects as well as commercial law. Keeton was an enthusiastic proponent of a school of comparative law: a scheme embodying this idea was apparently approved by the university senate in $1925,{ }^{15}$ and the new governor Sir Cecil Clementi, himself a legal scholar who had become well-versed in aspects of Chinese land law, supported it. ${ }^{16}$

14 G B Endacott, "The Beginnings" in Brian Harrison (ed), The University of Hong Kong: The First 50 Years (Hong Kong: Hong Kong University Press, 1962) 29.

15 See the note in (1928) I Hongkong University Journal of Law and Commerce 7.

16 Keeton, "Forty-five Years On" (1971) 1 HKIJ 6.
Alas, in his farewell address to the university's Law Society in April 1927, George Keeton admitted: "I myself am the only representative of what ought to be a great and flourishing School of Law . . ."17 Despite having been promoted to Reader in Law and Politics, Keeton was embarking for a distinguished academic career in England. Whilst he had been in Hong Kong, however, he said:

". . I have had a single object constantly before me - the extension of legal studies. Falling to accomplish that object through the existing University organisation (since, as the Vice-Chancellor pointed out at the last degree congregation, we still lack the 'few paltry dollars' necessary to equip the required Professorships and Lectureships), I have sought to approach the same end through the Law Society and the Law Journal." 18

II.5. A law journal.

"The Law Journal" was a publication which began life in 1926 as the Hongkong University Law Journal, though it apparently only managed three issues before falling "a victim to the tyranny of financial stress."19 Its aims were "to promote the scientific study of Chinese Law, and to help forward, in some measure, the process of legal regeneration in China." ${ }^{20}$ In April 1928 it merged with a commerce journal, and Volume I, No 1 appeared a year later, and there were various issues during the 1930s. The last was probably in 1940 ,

II.6. Non-Hong Kong emphasis.

Thus in the 1920s a beginning was made in the academic study of law in Hong Kong and in the development of a legal literature. But Keeton's ideas

17 Printed in (1928) I Hongkong University Journal of Law and Commerce 82. 18 ibid.

19 See editorial comment in ibid, 2.

20 See editorial note in (1927) I Hongkong University Law Journal 79. 
concerned far broader legal perspectives than the law of Hong Kong, ${ }^{21}$ and even when final year students in the Department of Commerce contributed notes on recent commercial law cases for the first issue of the law journal the cases they chose for commentary were all from the English courts. Further, the law journal and its successor published virtually nothing on local law: the overwhelming emphasis was on the law and jurisprudence of China.

\section{II.7. The development of university law teaching.}

It was some time before the University of Hong Kong abandoned its self-image as a standing contribution to the government and people of China: before World War II, for example, it had never been suggested that a course of legal studies leading to a qualification for the practice of law in Hong Kong was at all appropriate. Thus when a plea was made in 1930 for legal education in Hong Kong the only concern was that lawyers in China be properly trained primarily in the interests of foreign businessmen:

"It would be a short-sighted policy not to establish a law school in

Hong Kong, because of the fear of producing a superfluity of half-baked lawyers as in India, when the chief complaint of the businessman is that the Chinese judges have netther the proper training, traditions or [sic] spirit. The more lawyers China has trained in British traditions the more satisfactory will be the position of foreign traders. Lawyers there will be anyway. Why not have well trained ones?" ${ }^{22}$

But after 1945, and particularly after 1949, local concerns became paramount. In the post-war years, as Evans points out,

"it occurred both to the University and to the legal profession that Hong Kong needed to look again at its legal education, the University because Law was, perhaps, the only major discipline not represented in its curricula and the profession because it was becoming apparent that the existing system of qualification [principally in England] was not meeting entirely the needs of Hong Kong." 23

21 See note 16 above.

22 W Astor, in a memorandum sent to the Foreign office in July 1930: F0371/ 14724, p 99 (Public Record Office, London).

23 D M Emrys Evans in Legal Education in Hong Kong (Hong Kong: Hong Kong University Press, 1974) 3.
The Department of Extra-Mural Studies at the university hired teachers in the 1960s to prepare students for the University of London external LLB exams, and so, for perhaps the first time since Professor Keeton left Hong Kong, academic lawyers existed in the colony. The Department of Law, now the School of Law, was established in 1969 with a teaching staff of four. It has expanded during the 1970s, and is still expanding, while the Hong Kong Polytechnic has also recruited full-time law teachers. Thus it is only very recently that there has been a group of law-trained personnel who might be expected to contribute to legal scholarship. In addition, the primary teaching function of the university's academics relates to the law of Hong Kong, not of China, and their writings naturally reflect this.

II.8. Amount of legal literature.

Until the Hong Kong Law Journal began publication (see para III.14 below) there was only a minute collection of secondary materfal on Hong Kong law: occasional committee reports, sporadic articles, one book purporting to be a history of the laws and courts of Hong Kong (published in 1898) and another on taxation law by a tax consultant. Civil servants have never been encouraged to write for publication, legal practitioners never found the time, and judges and magistrates, if they were ever interested, were probably inhibited by a vague notion that extrajudicial legal commentary is improper. There has been, in relative terms, a veritable explosion in the realm of secondary legal literature since 1971.

Imported v locally produced materials

II.9 The use of English materials.

As mentioned in para I.5(4) above, English legal literature is often quite suitable for use in Hong Kong, in many areas needing only very minor qualification. In the field of mercantile law, for example, the statutes are virtually identical, the common law rules are the same, and there is no topic for which local variants have developed to any great degree. It is unlikely that a book on Hong Kong mercantile law could be produced cheaper than an English rival, and preparation of such a book would, in any event, have to be 
considered low on any order of priorities referring to local legal literature. The only advantage a local book might have is in the use of examples more related to a student's experience.

\section{II.10. The scope for local legal literature.}

There are other areas, however, where the legal literature of another jurisdiction is not suitable. Obviously, the constitution of Hong Kong is sui generis and must be studied as such, however useful and valid it may be to consult works on other British colonies; Hong Kong family law contains its own special problems; landlord and tenant law is based on a complicated set of provisions designed in response to specific historical circumstances and social conditions. Particular topics, too, involve a legal situation unique to Hong Kong (for example, the law of corruption). There is ample room for lengthy studies on many aspects of Hong Kong law. In addition, of course, the constant review of legal developments, by means of notes and commentaries on recent cases and statutes, editorial comments and critical articles on the legal system, is a valuable locally-generated contribution to legal literature.

\section{CHAPTER III}

\section{EXISTING MATERIALS}

Statutes

III.1. The statute book described.

The Laws of Hong Kong, 1964 edition, was published in 1966 and brought into operation on February 1, 1967. ${ }^{24}$ Its characteristics are:

(1) It originally contained every law enacted in the colony which was in force on December 31, 1964. The adoption of a loosebooklet format, and the imposition on the Attorney General of a duty to publish an annual revision of amended ordinances, enables the laws to be kept up to date.

(2) Each ordinance is given a chapter number and is placed in a volume together with its subsidiary legislation, if any. Ordinances on cognate subjects were originally grouped together, but as time goes by it is increasingly difficult to maintain that system. For example, the "Star" Ferry Company (Services) Ordinance is now between Third Parties (Rights Against Insurers) and Venereal Disease.

(3) Each section or subsection, as appropriate, is annotated with its history, indicating origin and any repeal, replacement or amendment.

(4) The contents of the 1964 edition, as it stands in 1979, are quite comprehensive:

24 See the Attorney General's first reading speech for the Revised Edition of the Laws Bill 1965 in LegCo Proc 1965 (Nov 24) 587. 
Vol 1: Preface

Revised Edition of the Laws Ordinance (No 53 of 1965)

Table of Contents (chapters listed in numerical order with short title and subsidiary legislation, page designation and year of current edition)

Chronological table of ordinances (year and original number, subject and remarks (eg, whether disallowed, when repealed))

Chapters 1 to 4

Vol 21: Chapters 1111 to 1129

Appendix I: Letters Patent, Royal Warrants, Regulations and Miscellaneous Instruments

Appendix II: English Acts applicable to Hong Kong by virtue of terms thereof or made applicable by order in Council or ordinance (the Acts are merely listed, not reprinted) Appendix IIA: English Acts applicable to Hong Kong by virtue of the Application of English Law Ordinance (cap 88) (texts reproduced but for reference only)

Appendix IIB: List of references to United Kingdom statutes

Vol 22: Appendix III: Her Majesty's Orders in Council, Rules etc which are applicable to Hong Kong

Vol 23: Appendix III (cont)

Appendix IV: A selection of constitutional documents, conventions and treaties

Vol 24: Minor amendments (amendments not sufficiently extensive to justify publication of a new revised edition of each relevant chapter are contained in this annual cumulative booklet)

Separate volume: Index: Part I (ordinances and subsidiary legislation) and Part II (Acts, Orders in Council etc)

Lists of appointments (under various ordinances)

List of previous editions extracted from the Laws of Hong Kong
III.2. In praise of the statute book

Judged by the criteria suggested by William Twining in a lecture delivered in Lagos in 1976, the statute book in Hong Kong merits considerable acclaim. It is:

(1) comprehensive, in that it contains all ordinances and subsidiary legislation in force and constitutional documents, applicable Acts of Parliament, Orders in Councll etc (that is, nearly all enacted law is reproduced therein; only some enacted law originating outside Hong Kong is not reproduced, but it is nevertheless listed);

(2) up to date, if the user's noting-up system is efficiently administered;

(3) reliable (Indeed, authoritative);

(4) accessible to main users in that, although very expensive, most practising lawyers have their own sets, government lawyers and the judiciary are given easy access to it, and at least three different law libraries situated near the main groups of users have up to date copies. It can also be consulted in public libraries;

(5) efficient and convenient to use: by use of the Index, it is easy to find the chapter number and volume of any item of legislation, and the printing and paper quality are of a high order. Individual ordinances, which are stapled in booklet form, may be easily taken out and consulted separately from their bulky folders.

In the opinion of $\mathrm{G} \mathrm{W}$ Bartholemew

"the revision undertaken in Hong Kong is incomparably the best which has appeared to date. It satisfies to the fullest extent possible the criteria of completeness, conciseness and up-to-dateness and will surely remain a model to which all other revisions will aspire." 25

III.3. Criticisms of the statute book.

There are a few criticisms, however:

(1) the index is very basic and provides scarcely any more information than the table of contents. It is probably usually adequate for the needs of practising lawyers but it is of little assistance to the academic

25 "Statute Law Revision" (1971) 1 HKLJ 274, 287. 
researcher. Nevertheless the Rules of the Supreme Court and the merchant shipping legislation are separately indexed;

(2) in practice there is often considerable delay in the issue of new booklets for ordinances which have been much amended.

III.4. The government Gazette.

In addition to the Laws of Hong Kong, the government Gazette is a useful source of legislation, and is essential for very recent ordinances or amendments and for earlier editions. Bills are published in one supplement to the Gazette, legal notices (dealing with the commencement of some ordinances, signification of non-disallowance, proclamations etc) are in another, the complete original texts of ordinances are in another, and subsidiary legislation is in a fourth. A good library has each supplement separately bound each year. There is no difficulty finding any item of legislation for any year, especially if the chronological list of ordinances from 1843 to date, found in Volume 1 of the Laws of Hong Kong, is consulted.

Law reports

III.5. The Hong Kong Law Reports described.

This series (see para II.2 above) is edited in the Attorney General's department. It has been published without a break (except for the Second World war) since 1905 and comes out quarterly, usually between six and nine months after the period covered. Reports of selected cases before the Court of Appeal and the High Court and of cases before the Judicial Committee of the Privy Council on appeal from Hong Kong are published. In a supplement are reports of cases in the District Court. There are a separate loose-leaf volume of tax cases published by the Government Printer at the behest of the Inland Revenue authorities and a folder of printed practice directions. The law reports are not proper "reports" in the sense that a barrister attended in court and personally vouchsafed the accuracy of the printed proceedings; they consist solely of the written judgment as it emerged from the judges' chambers, supplemented by headnotes and index. Digests, consolidated indices, tables of cases and statutes and noters up are also provided.
III.6. Assessment of the Hong Kong Law Reports.

Again using the criteria suggested by Professor Twining in Lagos, the Hong Kong Law Reports are:

(1) reasonably comprehensive: most of the important cases in the District Court and above are reported; there are occasional omissions, of course, and some practitioners consider there is an over-emphasis on criminal cases

(2) not especially up to date, but the delay is not intolerable;

(3) reliable;

(4) accessible to main users: as for the Laws of Hong Kong, the reports are expensive but many practitioners have a full set and judiciary, law officers, untversity teachers and their students have easy access to library coples;

(5) reasonably efficient and convenient to use. In the last couple of years there have been minor improvements in printing style and editing. Although the indexing is still insufficiently detailed, the semi-official digests and Indices compiled by Frank Addison (formerly of the District Court, now a puisne judge) and other published aids are of considerable assistance in using the reports.

III.7. Reform of the Hong Kong Law Reports

It is not quite fair to place Hong Kong's law reports in what Alan Milner calls "the classic English tradition: randomly selected, negligibly edited, atrociously indexed and sporadically published." Nevertheless, this is an area where improvements are needed. An editorial in the Hong Kong Law Journal in $1978^{26}$ suggested the desirability of reform, and later in the year the Attorney General established a working party to consider proposals made in a separate memorandum which I submitted to the government. The working party's recommendations (see appendix 1) have not as yet been implemented and their fate is uncertain.

26 (1978) 8 HKLJ 142 
III.8. Unreported judgments.

In theory, all written decisions of the Supreme Court of Judicature since 1968 are available, in cyclostyled typescript, on file in the supreme court library; many of them are circulated by the registrar of the supreme court to the School of Law at the university, where they are also filed and spasmodically indexed. The supreme Court library's system, similar in objective to the Bar Library transcripts scheme, is unfortunately not very efficiently run: the collection is incomplete, the cases are often out of order or borrowed by the judges, and xeroxing is inordinately expensive. If properly indexed, and if greater care is taken on their filing and preservation, these typescripts would be a much more useful supplementary source of "reports"

(these are, in fact, what gets printed in the Hong Kong Law Reports, and when in the library file they are only lacking index headings and headnotes).

III.9. Hong Kong Law Journal road traffic summaries and sentencing section. In addition to the official Hong Kong Law Reports, the Hong Kong Law Journal has since 1974 published summaries of cases involving claims for personal injuries and fatal accidents. Although not strictly reports, the courts are now accustomed to citing these cases according to their HKIJ reference and they even, it seems, sometimes rely on the journal summaries exclusively. since 1978 a digest published in the journal has provided a brief guide to current sentencing practice in the colony's courts.

\section{III.10. Circulated headnotes.}

The editor of the Hong Kong Law Reports prepares each month draft headnotes of cases being considered for inclusion in the reports. These are circulated round the profession for comment. The Hong Kong Law Journal also publishes headnotes (prepared by its own contributors) of cases deemed worthy of a commentary .

\section{III.ll. Tribunal decisions.}

Beginning in 1977, selected Lands Tribunal cases have been printed and published, but these are the only tribunal proceedings which are regularly reported. Application to the appropriate registrar, which would not invariably be successful, would be necessary for a practitioner or researcher to see written judgments emanating from a tenancy tribunal, the Small Claims Tribunal or the Labour Tribunal. Magistrates' decisions are not normally available.

Legal archive

III.12. The Public Records office.

Hong Kong's historical documents have only recently begun to be treated with respect - too late, alas, for a great many of them. In particular, the loss of government records during the Japanese occupation 1941-45 was considerable yet, after the war, records continued to be haphazardly stored and indifferently preserved. In July 1972, however, the Public Records Office (PRO) was established. According to the Government Archivist:

"The main function of the [Public Records office] is the conservation of all government records of permanent value for official reference and private research. More specifically, this means all documents which possess value for:

(i) documenting the constitutional and legal basis of government;

(ii) documenting the origin, development, organisation, functions, policies and substantive activities of government departments;

(iii) protecting the rights and privileges of private citizens and organisations; and

(iv) research into political, social and economic affairs and the history of the community." 27

There are huge gaps in the material which has been collected so far and it will be a long time before all available records have been sent to the PRO and properly catalogued. Some useful documents have already appeared, however, and, with the recent acquisition on microfilm of the C0129 series of governor's despatches, the future legal historian of Hong Kong already has enough material with which to begin work. For example, files transferred from the Registrar General's department include Land (Crown Lease) Registers 1843-1975, Miscellaneous Maps, Plans and Charts of Hong Kong (1845-1954),

27 Ian Diamond, "The Paper Chase" (1974) 14 Journal of the Hong Kong Branch of the Royal Asiatic Society 12, 23. 
Crown Rent Rolls 1843-1924, 1935-1958, and case files relating to dissolved local companies (1885-1970). In general there is a thirty year rule applying to such materials, though government sensitivity on some matters might restrict access to particular files.

Secondary materials

\section{III.13. The paucity.}

Rear's chapters on labour law in Chinese Labour under British Rule provide a comprehensive coverage amounting to a text, but otherwise there is no textbook for practitioners or students of Hong Kong law. Penlington's recent book Law in Hong Kong is too thoroughly mediocre to qualify and Newton's Hong Kong Taxation is aimed more at taxpayers than at students. There are no casebooks, no lengthy monographs (other than O'Brien's articles on landlord and tenant law reprinted from the Hong Kong Law Journal), and no major reference works except a series of digests and indices prepared by Frank Addison. There are no full-length biographies of legal personages in Hong Kong and no primarily legal studies by anthropologists. Writings on Hong Kong law are largely restricted to journal articles, especially in the Hong Kong Law Journal.

III.14. The Hong Kong Law Journal.

This journal is published by a private company financed by practising lawyers and is edited in the School of Law, University of Hong Kong. It began publication in 1971. It is published three times a year, in January, May and September. Each volume has about 400 pages and contains articles, notes and comments, notes of recent cases and statutes, summaries of personal injuries and fatal accidents cases, book reviews and editorial comments. There are annual tables of cases and statutes cited and there is an annual index. Although material on the law of other countries in the Asian region is occasionally included, and a few articles have only a tenuous link with things legal, the bulk of the material is directly concerned with Hong Kong law. This journal is by far the single most important source of secondary legal literature in Hong Kong.

\section{III.15. Financial viability.}

It is significant, however, that the Hong Kong Law Journal is not a viable commercial undertaking. Founded with an Asia Foundation subsidy, the publishing company does not lose money but is dependent upon the unpaid (or only nominally paid) services of a business manager and editors and subeditors and upon the profits from the annual series of law lectures for practitioners. In the past it has relied on the occasional largesse of its shareholders, a source of finance which would no doubt be available again if need arose in the future.

III.16. Hong Kong Law Journal Limited.

The publishing company which is responsible for this journal has other achievements to its credit. It has published three annotated ordinances and has organised six highly successful annual two-day seminars for practitioners. The proceedings of these seminars have been published and are a significant contribution to the corpus of legal literature in Hong Kong. Hong Kong Law Journal Ltd would willingly sponsor other publications on Hong Kong law but is hampered by a lack of copy and by sufficient editorial and sub-editorial assistance.

III.17. Other periodicals.

Apart from the Hong Kong Law Journal, the only periodicals dealing with Hong Kong law are Obiter Dicta and Justitia. Obiter Dicta is the mimeographed newsletter of the Magistrates Association. First published in 1974, it provides comments on legal developments of particular interest to magistrates. It is an engagingly edited little periodical, but unfortunately its cheap format makes it difficult to use as a reference tool. Justitia is an annual collection of essays on legal topics by students of the School of Law, University of Hong Kong. Each contributor has invariably rewritten the dissertation he was required to submit in the second year of the LLB programme. There are obvious limitations to the usefulness of student work (which is undertaken more as a training exercise in legal writing than in the hope of producing valuable original research), but the dissertations are written under staff supervision and some of them are very good. In 1977-78 the 
students completed a special study of the Small Claims Tribunal for publication in Justitia.

III.18. The cost factor.

It has been noted in para II.7 above that it is only recently that full-time law teachers have been appointed in Hong Kong. That is one obvious reason for the paucity of secondary legal literature in the colony. Another is the tiny size of the potential market. A third is the condition which has affected legal publishing all over the world: rapid increases in costs.

\section{CHAPTER IV}

\section{RESOURCES AND CONDITIONS}

Personne1 resources

IV.1. Potential authors.

Clearly, the personnel resources in Hong Kong for the development of a local secondary legal literature are very limited - in effect they are restricted to the university's law department. This is not to say that law officers of the Crown, barristers, solicitors, members of the judiciary or even students cannot make valuable contributions to legal literature; but for a sophisticated, sustained piece of research and writing only university academics are likely to have the time and opportunity. Polytechnic law teachers spend too much time teaching and do not have the facilities at their place of work for legal research. This means that the hope of a developed corpus of literature devoted to Hong Kong law primarily rests with the full-time teachers employed to teach law at the University of Hong Kong and whose duties include "contributing to scholarship."

\section{IV.2. The record of the teaching profession.}

The eight volumes of the Hong Kong Law Journal and the five booklets of law lectures for practitioners are testimony to the contribution already made by members of the teaching profession. Each item of literature thus contributed is, in the main, doctrinal (expository), quite short, and was researched and written over a relatively short period of time. This type of legal writing is likely to continue, for it (1) is necessary and useful, (2) is not especially difficult to produce, and (3) fills up the curriculum vitae. This last is not intended to be cynical: it merely recognises that promotion boards in Hong Kong university are no less impressed than such bodies elsewhere by the length, rather than the quality, of lists of publications. The more detailed, thought- 
ful analysis and the long-term research project are not superficially as attractive on the record of a candidate for promotion. Nevertheless, longterm research has been undertaken and will no doubt continue.

\section{IV.3. Teachers in private practice.}

The university provides vocational teaching for students who enrol for the oneyear Post-graduate Certificate in Laws (PCLL). This type of teaching can, of course, best be carried out by teachers who are qualified, experienced practitioners of the law. It is reasonable to assume that staff members who fall into this category are less likely than their more "academic" colleagues to contribute to legal literature. In the first place, since they are usually permitted, indeed encouraged, to engage in private practice, they will usually do so, especially as private practice in Hong Kong is quite lucrative. Secondly, the School of Law operates its own legal aid and advice scheme, which relies heavily on the services of practising members of staff. The demands of teaching, practice on one's own account and participation in the legal aid scheme leave little time for research and writing.

\section{IV.4. Opportunities.}

The university teacher who wants to, however, can usually find a fair amount of time to devote to research, both in term-time and in vacations. Long leave (which in effect takes the place of sabbatical at the University of Hong Kong) can be used exclusively for this purpose. Facilities will usually be adequate, though of course this question depends on the type of research being conducted.

\section{Financial resources}

IV.5. Grants for research and publishing.

The University of Hong Kong has funds allocated to assist those engaged in research, and in the past successful applications for grants have been made by members of the law department. Generally speaking, doctrinal legal research and writing do not need extensive financial support, so long as library services are adequate. When it comes to publishing, however, financial resources are probably non-existent: if a worthwhile book could not find a publisher because of expected small returns from sales, there is no formal means by which money can be made available. It may be possible to find charitable sponsors for a particular publishing project, but this has not been truly tested. A serious work lacking in popular appeal could not, unfortunately, be guaranteed a publisher, however valuable a contribution it may be to legal scholarship. For example, in the early 1970s, a proposal made by John Rear for a book on Hong Kong's laws and legal system, upon which a number of academics were prepared to collaborate, foundered because of market factors: despite such a work's potential value for students, even the Hong Kong University Press was not prepared to risk capital on it.

Facilities for research

\section{IV.6. Law libraries.}

For doctrinal research, the three main law libraries in Hong Kong between

them probably cover the Commonwealth common law world reasonably extensively. The main deficiency is in legislation from other areas, text-books and monographs, though if necessary the secondary materials can be obtained from overseas on interlibrary loan. As pointed out above, Hong Kong's law reports and statutes are readily available and generally easy to use. Secondary literature on Hong Kong law is, of course, so sparse that it is a simple matter for public and, indeed, private libraries to stock it all.

\section{IV.7. Non-doctrinal research.}

For historical, sociological or anthropological legal studies the facilities are not impressive. But for the last fifteen years or so the collection and publication by the government of raw data on the economy and society of Hong Kong has been increasingly comprehensive; and the Public Records office is processing fairly large quantities of historical documents. A start has been made, and in most areas it would be the faint-hearted scholar who gave up a research project for lack of material. For these types of research, however, law teachers are not well qualified, both because in fact only one of them (in 1979) can use Chinese materials and because few have any familiarity with or formal training in other disciplines. 


\section{CHAPTER V}

\section{FUTURE DEVELOPMENTS}

V.1. The size of the market.

The legal profession in Hong Kong is expanding quite rapidly and the number of students taking law courses has increased considerably over the last few years and will probably continue to increase. The potential market for legal publications can only grow, though it will never be very large.

\section{V.2. Legal research unit.}

The School of Law at the University of Hong Kong is considering seeking funds for the establishment of a legal research unit. If established, the unit will encourage, promote, plan and facilitate research into legal topics in Hong Kong and, where possible, assist in the publication of data, research aids and individual studies. The success of the unit would mean a significant boost to the development of a local legal literature.

\section{V.3. Computerisation of legal material.}

A lecturer in the university's law school has begun a programme for the computerisation of personal injuries and fatal accidents cases in Hong Kong. It is designed as an information storage and retrieval system, and it could be extended to cover other types of legal material and to perform other jobs (indexing, for example). Computerisation could well render some species of legal literature redundant.

v.4. Hong Kong Law Journal Limited.

The development of legal literature in Hong Kong is, almost certainly, largely dependent upon the company which has so far produced eight volumes of the Hong Kong Law Journal, five booklets of law lectures for practitioners, and three annotated ordinances. "The company" is, in reality, one part-time secretary: the "business manager" is a busy $\mathrm{OC}$ and the editors and sub-editors are lecturers. There is an obvious limlt to the range of publications it can put out, and, indeed, even continual production of the journal itself cannot be guaranteed, depending as it does on so much of the time, energy and commitment of unpaid personnel. If suitable works are submitted for publication, Hong Kong Law Journal Limlted will do its best to publish them, but its limited resources are unlikely to improve dramatically in the near future.

\section{v.5. Other publishers.}

The Hong Kong University Press is a potential publisher of local legal materials, but in the past it has not been able to subsidise publications and has been very slow in producing 1ts books. Commercial publishers are of course even more constrained than others by the need to show a profit, and it is unlikely that narrowly legal literature would appeal to them as a viable publishing proposition (fringe material, however, will be acceptable: Oxford University Press, for instance, have published England and Rear, Chinese Labour under British Rule, Hopkins (ed), Hong Kong: The Industrial Colony and Miners, The Government and Politics of Hong Kong). Yet some interest is currently being shown by commercial publishers in some types of legal material.

V.6. Needs.

The first priority is to consolfdate and secure what has already been achieved. The Hong Kong Law Journal must continue its good work; the annual seminar for practitioners and the resulting booklet of lectures must be retained; the series of annotated ordinances should be expanded by the addition of new titles. Secondly, resources must be provided, if and when necessary, for the publication of any worthwhile legal material which is seeking a publisher. Thirdly, the preparation of works on Hong Kong law should be actively encouraged. Priority here should be given to studies of those aspects of Hong Kong law which are unique - in particular, to studies of the legal system. 


\section{v.7. The meeting of needs.}

Legal literature in Hong Kong is characterised by part-time production: the editing of the Hong Kong Law Reports is an extra (and usually unwelcome) duty imposed on the law reform section of the Attorney General's chambers, the Hong Kong Law Journal emerges from a busy teaching department, practitioners or practising academics strive to keep the occasional weekend free to write a lecture or a note for publication. But for the needs mentioned in para V. 6 to be met, some kind of funded institutional support is necessary. The proposed legal research unit could fulfil a role here. It could possibly provide an editor/sub-editor for the Hong Kong Law Journal, someone who would be free from the demands of teaching and researching on his own account. The unit might also, under some kind of arrangement with the government, assist in the editing and publishing of the Hong Kong Law Reports. In effect it would become a subsidised, non-profit-making publishing company. Alternatively, Hong Kong Law Journal could be supported to the extent that it could hire fulltime staff to look after the journal and other publications.

\section{V.8. Conclusion}

Any kind of recommendation must be tentative, for there are many practical difficulties: securing a source of funds, co-ordinating legal research unit activities with Hong Kong Law Journal Ltd ventures, finding sub-editorial staff, and so on. A realistic assessment would probably admit that the near future of secondary legal literature in Hong Kong will be, at most, no different from its near past: a regular professional journal, an annual book of lectures, and the occasional booklet, Justice report or annotated ordinance and the rare book-length study. The output, however valuable, will be small, unco-ordinated and haphazard. Yet even this is insecure while there is no full-time staff to organise the publication of finished work. If the development of a secondary legal literature and the improvement of primary legal source-material are worthwhile, financial provision must be made for the support of a publisher undistracted by other duties.

\section{APPENDIX 1}

\section{Extract from the interim report of the \\ Attorney General's working party}

on law reporting

Proposals for Reorganization

Emerging from the dialogue between the Attorney General and the legal professional bodies and discussions which the Chairman of the Bar Association had with the previous Chief secretary a memorandum on law reporting in Hong Kong containing proposals fro the reform of the present system was produced by Dr P Wesley-Smith of the School of Law, University of Hong Kong [not reproduced] . . . The principal proposal that there should be a three-tiered structure consisting of an Editorial Board, an Editor and an Editorial Committee was accepted by the Attorney General in principle who instructed that a Working Party be set up to consider the proposal and how best to give effect to it.

Members of the Working Party are:

$\begin{array}{ll}\text { Mrs K Y Chau } & \begin{array}{l}\text { Editor of the Hong Kong Law Reports } \\ \text { (Chairman) }\end{array} \\ \text { Mr H Litton, QC } & \text { Chairman of the Bar Association } \\ \text { Mr F Cheung } & \text { Representative of the Law Society } \\ \text { Dr P Wesley-Smith } & \text { Lecturer, School of Law, University } \\ & \text { of Hong Kong }\end{array}$

The Judiciary declined the invitation to send a representative.

Deliberations of the Working Party and its Recommendations

The Working Party held its first meeting on the 9th October 1978. First consideration was given to the proposal by Dr Wesley-Smith that the present system should be replaced by a three-tiered organisational structure consisting of the Editorial Board, the Editor and the Editorial Committee. 
Members were of the view that the proposed system would certainly be an improvement. The Editor who hitherto has sole responsibility for producing the Reports would under the new system be able to consult the Editorial Board on policy matters. The actual hard work of editing which would be performed by specialists (as far as possible) should enhance the quality of the reports. The Working Party recommends the acceptance of the proposal for the setting up of a three-tiered organisation structure.

\section{Editorial Board:}

Members of the Working Party saw no difficulty in the establishing of the Board whose functions are mainly supervisory and advisory. Editor:

As proposed and accepted, the Editor would continue to be employed in the Legal Department. No dfficulty is envisaged in formulating the duties of the Editor.

\section{Editorial Committee:}

For the purposes of law reporting the law would be broadly divided into five areas, viz:

1 Commercial and business law (Including companies, contracts, banking and taxation)

2 Constitutional law and legal system (including administrative law, civil liberties, interpretation of statutes)

3 Criminal law and procedure (Including evidence)

4 Property law (including trusts and estates, landlord and tenant, industrial and intellectual property)

5 Miscellaneous (family law, labour law, civil practice and procedure and others which do not fall under $1,2,3$ or 4 ).

It is also envisaged that with the increase of written judgments from the Court, further sub-divisions may be necessary.

It was agreed that the Editorial Committee should be made up initially of 10 lawyers, 2 for each division and they should be "specialists" (as far as possible) in that division of the law. The "specialists" would be responsible for the actual editing, that is, preparing the headnotes of judgments for reporting, indexing and editing the judgments. It is the firm belief of the members of the Working Party that in order to obtain prompt and good reporting some monetary payment ought to be made to members of the Editorial committee. It was agreed that a fair and reasonable sum to be paid to each member by way of an honorarium should be HK\$20,000 a year. The sum has been arrived at after considering the level of fees payable to lawyers performing duties under the new Magistrates Court Legal Assistance Scheme.

The Working Party decided that before proceeding further with its deliberations an interim report should be submitted to the Government with a recommendation that Government provide an annual fund of $\$ 200,000$ for the purpose of remunerating members of the Editorial Committee of the Hong Kong Law Reports when it is formed. The reasons in support of the recommendation are -

1 Unless there is an availability of funds which only Government could provide the reform as envisaged could not come to fruition.

2 Accurate and prompt publication of law reports is essential to the Hong Kong system of law where the doctrine of stare decisis applies. Government as administrator of the Law ought to be responsible for the proper service of law reporting.

3 Although it is appreciated that the cost of the editorial services rendered by members of the Legal Department is not recovered, the cost to Government in this respect is somewhat balanced by the fact that Government obtains the Reports at present free-ofcharge whilst the private sector pays. With the introduction of the new scheme the reduction in the level of Government's contribution must be taken into account to offset the money required to pay members of the Editorial Committee.

4 By pursuing a more agressive sales promotional procedure a wider market both locally and overseas for the improved law Reports may be obtained which may in time have the effect of reducing or annulling the subsidy which Government is recommended to provide. 
Recommendations

1 Subject to the acceptance of Recommendation 2 that with a view to improving the service of law reporting in Hong Kong arrangements for appointing an Editorial Board, Editor and Editorial Committee be effected on or before lst January 1979.

2 That Government provides an anmual fund of HK\$200,000 to be used for the payment of honoraria to members of the Editorial committee.

24 November 1978

\section{APPENDIX 2}

Articles and books concerning Hong Kong law

The list presented below is a fairly comprehensive coverage of English

language writings on local law outside the pages of the Hong Kong Law Journal, Justitia and Obiter Dicta. No attempt has been made to list government reports or legal commentaries published in the Far Eastern Economic Review or in the local newspapers. Primary materials and their aids (digests, annotations, indices and so on) have not been included.

Bush, John. Guidebook to Taxation and Investment Law in Hong Kong (Sydney: $\mathrm{CCH}$ Australia Ltd, 1978): an overview of taxation and investment law written for a non-Hong Kong audience.

Chinese Marriages in Hong Kong (1967): a report by the Sub-Committee of the Hong Kong Bar Association on Chinese Marriage.

Coates, Austin. Myself a Mandarin (London: Frederick Muller Ltd, 1968): subtitled "Memoirs of a Special Magistrate," it is a collection of amusing anecdotes rather than a book about Hong Kong law, although it gives an admirable picture of a British magistrate administering Chinese custom in the early post-war New Territories.

Collins, Charles. Public Administration in Hong Kong (London: Royal Institute of International Affairs, 1952)

Endacott, George B. Government and People in Hong Kong, 1841-1962 (Hong Kong: Hong Kong University Press, 1964): subtitled "A Constitutional History."

England, Joe, and Rear, John. Chinese Labour under British Rule (Hong Kong: Oxford University Press, 1975): the collaboration of a lawyer and a specialist in industrial relations, this is probably the best sustained piece of work on Hong Kong law that has yet emerged. 
Evans, D M Emrys (ed). Legal Education in Hong Kong (Hong Kong: Hong Kong University Press, 1974): reports of the 1966 and 1969 working Parties on Legal Education.

Evans, D M Emrys: "Legal Education: The Hong Kong Experience" (1974) 5 Lawasia 243

Evans, D M Emrys. "Some Legal Aspects of Urbanisation in Hong Kong" in D J Dwyer (ed), Asian Urbanisation: A Hong Kong Casebook (Hong Kong: Hong Kong University Press, 1971)

Faulkner, Raymond J. "The Law of the Sea-Shore" in Brian Morton (ed), The Future of the Hong Kong Sea-Shore (Hong Kong: Oxford University Press, 19.78)

Faulkner, Raymond J. "Some Legal Aspects of Reclamation in Hong Kong" in Marjorie Topley (ed), Hong Kong: The Interaction of Traditions and Life in the Towns (Hong Kong: Royal Asiatic Society (Hong Kong Branch), 1975) 130

Fletcher, Clifford. A Police Officer's Guide to the Theft Ordinance (Hong Kong: Government Printer, 1970)

Glossary of Applied Legal Terms (Hong Kong: Hong Kong Government, 1975) : an English-Chinese legal dictionary.

Greenfield, D E. "Marriage by Chinese Law and Custom in Hong Kong" (1958) 7 ICLQ 437

Haydon, D S. "The Choice of Chinese Customary Law in Hong Kong" (1962) 11 ICLQ 231

Higgins, Mary Faith. Securities Regulation in Hong Kong 1972-1977 (The Netherlands: Sijthoff and Noordhoff, 1978)

Hooker, M B. "The Relationship between Chinese Law and Common Law in Malaysia, Singapore and Hong Kong" (1969) 28 Journal of Asian Studies 723 (the same author's Legal Pluralism (Oxford: Clarendon Press, 1975) contains discussion of similar themes in which Hong Kong material is used).

Hsueh Shou-sheng. "Administration of the New Territories, Hong Kong" [1960] Eastern Regional Organisation for Public Administration Review 29
Hsueh Shou-sheng. "Ecology and Administrative Reform in Hong Kong" in Hahnbeen Lee and Abelárdo G Samonte, Administrative Reforms in Asia (Manila: Eastern Regional Organisation for Public Administration, 1970)

Hsueh Shou-sheng. Government and Administration of Hong Kong (Hong Kong: University Book Store, 1962)

Jao, Y C. "Recent Changes and Trends in Hong Kong's Taxation" (1972) 26 Bulletin for International Fiscal Documentation 267

Jao, Y C. "Streamlining Hong Kong's Tax System" (1974) 28 Bulletin for International Fiscal Documentation 236.

Justice, Hong Kong branch. "Report on No-Fault Liability for the Compensation of Road Accident Victims" (Hong Kong: Justice, 1975) : a report prepared by $R$ J Faulkner.

Law Lectures for Practitioners 1974 (Hong Kong: Hong Kong Law Journal Ltd, 1974) : the first booklet to emerge from a series of annual seminars (see following four titles).

Law Lectures for Practitioners 1975 (Hong Kong: Hong Kong Law Journal Ltd, 1975)

Law Lectures for Practitioners 1976 (Hong Kong: Hong Kong Law Journal Ltd 1976)

Law Lectures for Practitioners 1977 (Hong Kong: Hong Kong Law Journal Ltd, 1977)

Law Lectures for Practitioners 1978 (Hong Kong: Hong Kong Law Journal Ltd, 1978)

Lo Hing-shing. Reminiscences and Observations (Hong Kong: privately published by the author, 1975): a small booklet of memoirs by a former magistrate.

McAleavy, H. "Chinese Law in Hong Kong: The Choice of Sources" in J N D Anderson (ed), Changing Law in Developing Countries (London: Allen \& Unwin, 1963) 258

Mills, Lennox A. British Rule in Eastern Asia (Minneapolis: University of Minnesota Press, 1942)

Miners, Norman. The Government and Politics of Hong Kong (Hong Kong: Oxford University Press, 2nd ed 1976) 
Newton, E. Hong Kong Taxation (Hong Kong: Department of Extra-Mural Studies, Chinese University of Hong Kong, 3rd ed 1974)

Norton-Kyshe, James William. The History of the Laws and Courts of Hong Kong (London: T Fisher Unwin, 1898; reprinted by Vetch and Lee, Hong Kong, 1971): a fat, two volume work of ill-organised, unsystematic anecdotes and aspersions masquerading as history, but nonetheless useful and fascinating to read.

O'Brien, Roderick. Landlord and Tenant Law in Hong Kong (Hong Kong: Hong Kong Law Journal Ltd, 1977): four articles reprinted from the Hong Kong Law Journal.

Penlington, Valerie. Law in Hong Kong (Hong Kong: South China Morning Post, 1978) : an attempt to survey a fairly broad spectrum of Hong Kong law; rather scathingly reviewed in (1979) 9 HKIJ 110.

Porter, R. "Child Labour in Hong Kong and Related Problems: A Brief Review" (1975) 111 International Labour Review 427

Rear, John. "British Labour Law in a Colonial Environment: The Hong Kong Experience" (1974) 3 Industrial Law Journal 138

Rear, John. "One Brand of Politics" in Keith Hopkins (ed), Hong Kong: The Industrial Colony (Hong Kong: Oxford University Press, 1971) 55

Rear, John. "The Law of the Constitution" in Keith Hopkins (ed), Hong Kong: The Industrial Colony (Hong Kong: Oxford University Press, 1971) 339: an indispensable account of the constitution.

Rear, John. "The Legal Regulation of Industrial Relations in Hong Kong" (1971) 2 Lawasia 36

Rear, John. This is the Law (Hong Kong: Government Press, 1968): transcripts of thirteen radio talks, separately published in Chinese and English.

Ribeiro, R A. "Contracts of Employment in Hong Kong" in C G Aronstein (ed), International Handbook on Contracts of Employment (Netherlands: International Bar Association, 1976)

Reibeiro, R A. "The Hong Kong Law Student" [1976] Journal of Malaysian and Comparative Law 241
Ribeiro, RA. The Law and Practice of the Hong Kong Labour Tribunal (Hong Kong: Centre of Ásian Studies, 1978): sub-titled "a socio-legal study on the problem of legal access"; most of the essay was published in a series of Hong Kong Law Journal articles.

Rider, Barry K L. "The Regulation of Insider Trading in Hong Kong" (1975) 17 Mal LR 310, (1976) 18 Mal LR 157

Roberts, P J. Valuation of Development Land in Hong Kong (Hong Kong: Hong Kong University Press, 1975)

Shen, James C Y. The Law and Mass Media in Hong Kong (Hong Kong: Mass Communications Centre, Chinese University of Hong Kong, 1972): severely criticised in (1974) 4 HKIJ 94.

The Government and the People (Hong Kong: Government Press, 1962): transcripts of low-level radio talks concerning various government departments.

The Government and the People (Second Series) (Hong Kong: Government Press, 1964): a sequel to the 1962 publication, including a chapter on the Legal Department.

Wesley-Smith, Peter. "Hong Kong" in Blaustein and Blaustein (eds), Constitutions of Dependencies and Special Sovereignties (New York: Oceana, 1976): a short introduction and bibliography to Hong Kong's constitutional documents.

Wesley-Smith, Peter. "The Walled City of Kowloon and its Law Today" in Marjorie Topley (ed), Hong Kong: The Interaction of Traditions and Life in the Towns (Hong Kong: Royal Asiatic Society (Hong Kong Branch), 1975) 119

Willoughby, P G. "Hong Kong: City State, Financial Centre, Low Tax Haven, Free Port and Historical Anomaly" (1976) 73 Law Society's Gazette 661

Willoughby, P G. "Hong Kong - Its Taxation, Companies and Securities Legislation" in Taxation and Investment Conference 24-26 May 1976 (Hong Kong: Asian Seminars Ltd, 1976) vol I, 89

Willoughby, P G. Hong Kong Taxation: A Miscellany (Hong Kong: South China Morning Post Ltd, 1977): a collection of newspaper articles.

willoughby, P G. "Umbrella Blown Inside Out by Typhoon" (1978) 97 LN 46 


\section{CENTRE OF ASIAN STUDIES PUBLICATIONS}

General Editor : Frank H.H. King

A. Occasional Papers and Monographs: (ISSN 0378-2689)

2. Jen Yu-wen and Sir Lindsay Ride, Sun Yat-sen: Two Commemorative Studies. (31 pp) HK\$ 15.00

5. Jen Yu-wen and Liricicic Study of the Cantonese Verb. (177 pp.) HK\$16.50

7. K.N. Vaid, Overseas Indian Community in Hong Kong. (108 pp.) HK\$16.50

8. Wong Shiu Hon, The theories of painting of Kao Chien-fu. (in Chinese with English abstract: 38 pp., 12 plates) HK\$15.00

9. Chan Lau Kit-ching, The Chinese Youth Party, 1923-1945. (62 pp.) HK\$15.00

10. David Chaney and David Podmore, Young Adults in Hong Kong. (250 pp.) HK $\$ 22.00$

11. W.K. Chiu, Quality Control in the Electronics Industry in Hong Kong. (40 pp.) HK $\$ 15.00$

12. Chuang Shen, Poetry of the four landscape masters of the late Yuan period. (200 pp., 10 plates: in Chinese with English abstract) HK\$22.00

3. John Wong, Chinese Land Reform in Retrospect. (32 pp.) HK\$11.00

15. G.C.P. Riches, Community Development in Hong Kong: Sau Mau Ping, a Case Study. (80 pp.) HK\$20.00

17. T.G. McGee, Hawkers in Hong Kong: a study of planning and policy in a third world city. (240 pp., plates and maps) $\mathrm{HK} \$ 40.00$

18. Fok Chan Yuen-yuen, A Perceptual Study of Tones in Cantonese. (197 pp.) HK\$36.50

19. Wong Siu-kit, The Genius of Li Po, A.D. 701-762. (64 pp.) HK\$20.00

20. R.J. Faulkner and R.A. Field, Vanquishing the Dragon: the law of drugs in Hong Kong. (Reprint, 103 pp.) HK $\$ 20.00$

21. Chin Szu-kai, Mao Tse-tung ssu-hsiang: nei-jung yü hsing-shih. (297 pp., in Chinese) HK\$20.00)

22. I.C. Jindow on Hong Kong. A sociological study of the Hong Kong film industry and its audience. I.C. Jarvie, Window on Hong Kong: $A$
(223 pp., tables and plates) HK $\$ 35.00$

23. Steve S.K. Chin (ed.), The Gang of Four: first essays after the fall - Selected Seminar Papers on Contemporary China, II. (200 pp., 1977) HK $\$ 30.00$

24. Lo Hsiang-lin, Liang Ch'eng: Chinese Minister in Washington, (1903-1907). (428 pp., in Chinese). HK $\$ 35.00$

25. R. Ribeiro, The Law and Practice of the Hong Kong Labour Tribunal: a socio-legal study on the problem of legal access. (122 pp.) HK\$30.00

6. Adam Y.C. Lui, Chinese Censors and the Alien Emperor, 1644-1660. (154 pp.) HK $\$ 25.00$

27. Raymond S.W. Hsu, The Style of Lu Hsun: Vocabulary and Usage. (430 pp., tables, figures) HK $\$ 75.00$

28. Mildred McCoy and Erik Kvan, Attitudes Towards Punishment: A repertory grid study of young offenders in Hong Kong. (87 pp.) HK\$15.00

29. Yasumitsu Nihei and others, Technology, Employment Practices and Workers: A Comparative Study of Ten Cotton Spinning Plants in Five Asian Countries. (136 pp.) HK\$40.00

30. Victor Fung-shuen Sit, Siu-lun Wong and Tsin-sing Kiang, Small Scale Industry in a Laissez-faire Economy a Hong Kong case study. (442 pp.) HK $\$ 60.00$

31. Steve S.K. Chin, The Thought of Mao Tse-tung: form and content. Translated by Alfred H.Y. Lin.(287 pp.) HK\$50.00 (See no. 21 for original Chinese version.) 
32. Lee Ngok and Leung Chi-keung (eds.), China: Development and Challenge, Proceedings of the Fifth Leverhulme Conference, Vol. I. 'Historical Experience and Marxism, Maoism and Politics'. (350 pp.) HK $\$ 75.00$

33. Jen Yu-wen, Su Jen-shan, eccentric genius of Kwangtung: his life and art. (in Chinese; 64 plates; $122 \mathrm{pp}$.; reissue) HK $\$ 15.00$

34. Frank H.H. King (ed.) The Development of Japanese Studies in Southeast Asia. (232 pp. reissue)HK\$25.00

35. Steve S.K. Chin (ed.), Modernization in China - Selected Seminar Papers on Contemporary China, III (300 pp.) HK $\$ 50.00$

36. N. Lee, W.S.K. Waung and L.Y. Chiu (eds.), Bitter Smile: Memoirs of Ch'en Kung-po 1925-1936. (in Chinese; Vol. I, 198 pp.) HK\$30.00

B. Bibliographies and Research Guides: (ISSN HK0441-1900)

4. Wong Shiu Hong, Paintings of the Lingnan School: an annotated catalogue of slides at the Centre of Asian Studies from the collection of Jen Yu-wen. (in Chinese with English explanations: $79 \mathrm{pp}$.) HK\$16.50

6. K.P. Chan, Chinese art and archaeology: a classified index to articles published in Mainland China periodicals. 1949-1966. (361 pp.) HKS45:00

7. David F. Ip, C.K. Leung and C.T. Wu, Hong Kong: a social sciences bibliography. (355 pp.) HK\$50.00

8. Maria C.K. Chu and Dorcas Hu (joint compilers), Chinese Periodicals in the Fung Ping Shan Library, University of Hong Kong. (242 pp.) HK\$30.00

10. H. Anthony Rydings, A Hong Kong Union Catalogue: Works Relating to Hong Kong in Hong Kong Libraries (976 pp., in two volumes) HK\$200 papercover; HK\$250 hardcover.

12. Elizabeth $\mathrm{Ng}$ (ed.), Directory of Current Hong Kong Research on Asian Topics 1978, with an Appendix on Macau. (197 pp.) HK\$40.00

13. Leung Pui-chee, Wooden-Fish Books: critical essays and an annotated catalogue based on the collections in the University of Hong Kong. (271 pp., in Chinese with English summary). HK\$35.00

14. Peter Yeung and Lai Shu Tim (joint compilers), Chinese studies: an index to collections of essays. (500 pp. in Chinese) HK\$100.00

15. Frederick Y.L. Ng (comp.), Theses for Higher Degrees, 1941-1977, University of Hong Kong. (127 pp.) $\mathrm{HK} \$ 20.00$

16. Frank H.H. King, Survey our Empire! Robert Montgomery Martin (1801?-1868), a Bio-bibliography. (320 pp.) HK $\$ 65.00$

17. Peter Wesley-Smith, Legal literature in Hong Kong. (39 pp.) HK\$10.00

Hong Kong dollar prices are for overseas and include mailing, etc. Unless payment accompanies overseas orders, a handling charge of up to HK\$10.00 per order may be added. U.S. dollar and sterling drafts accepted at the appropriate bank rate and should Kong. All prices subject to revision.

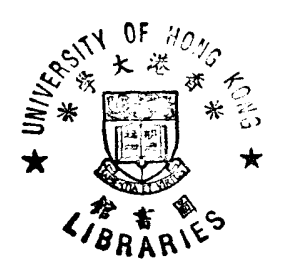


X12401920

This book is due for return or renewal on the date nown unless previously recalled. Fines may be unnd for late return.

P KT4364.9 W51

Wesley-Smith, Peter.

Legal literature in Hong Kong

Hong Kong : Centre of Asian

Studies, University of Hong

Display Tul 22 NOV 1999

Kong, 1979. 